\title{
Research on the Cultivation Model of Applied Innovative Talents for Postgraduates of Art Design Major
}

\author{
Weijun Zang \\ Xijing University (China Xijing 710123)
}

Keywords: Postgraduate of art design major; Applied innovative talents; Training model

\begin{abstract}
With the continuous expansion of the scale of higher education in our country, the current postgraduate of art and design major becomes a special type of postgraduate, and the demand for professional innovative talents in society is also constantly expanding. Based on the situation of applied talent cultivation for postgraduates in the art major, firstly, the article introduces the details of the integrated professional and re-planning curriculum system. Secondly, it focuses on the analysis and discussion of the cultivation strategy of the practical and innovative talents course. It also hopes to be relevant to the arts in China. The training and development of top talents provide a steady stream of backup resources and upgrade the overall level of China's modernization.
\end{abstract}

Since the beginning of the 1930s, China has successively established the names of art design major, practical art design major, design art major and so on. In higher education institutions, but due to the lack of normalization of related management work, the confusing phenomenon of disciplines and departments has also led to the fact that it is always difficult for real students to distinguish themselves from what kind of institutions they should choose. After the current standardization of education, most colleges and universities now regard arts and crafts as well as design art as integrated type of major. Art design is one of the professional catalogs of the master's degree. With the increasing demand of major employers for postgraduates in the field of art and design majors, the current state of development of arts and design graduates is analyzed as followings.

\section{Part One the Situation of Postgraduates of Art Design Major}

At present, China's current relatively complete art education model system mainly involves the graphic design and clothing, environmental art and other fields of the art academies, normal university and engineering colleges of the comprehensive colleges. From an objective point of view, even talents in the art design major must be divided into two different categories: liberal arts and science art. The Chinese students are more inclined to study the basics of humanities and painting, while the science is more concerned with the combination of practice and manufacturing design. Under the normal conditions, liberal arts postgraduates are relatively rare in practical application. They often fail to reflect the teaching value of comprehensive universities. This also leads to the comprehensive practical ability and application ability of art design postgraduates who graduated from liberal arts colleges. In addition, the postgraduates of China's art design major are relatively narrow in their employment. They must combine with other disciplines in the horizontal profession to generate more targeted specialties, thereby improving the advantages and values of postgraduate studies, and the more common similar professions include environmental art, computer art, display art, decoration and so on which belong to the category of master of art. Because the master of art has a good foundation in fine art and painting skills, it can fully use its own knowledge in industrial design, decoration design and display layout to reflect its value, and at the same time help related companies to obtain substantial economic benefits and social benefit. In spite of this, with the continuous development of the times, the employers' current emphasis on the composite, applied and innovative training effects of postgraduates in art design that has been increasing. This has also raised the educational and teaching work of related institutions. 


\section{Part Two Integrating Majors and Re-Planning Course System}

According to the current design level of art design education in China, students in the art design major in China are generally divided into graduate students, undergraduates, higher vocational education and other types, and the mode and application of training are not the same. This article takes the cultivation of applied talents for postgraduates of art design major as an example, and briefly analyzes the detailed strategies of integrating the majors and re-planning the course system. The analysis is as follows.

\section{Integration of Basic and Professional Courses}

For the postgraduates of art and design majors, the work of their basic professional courses has basically come to an end. However, combined with the requirements for the cultivation of compound talents and the training strategy model for the application of innovative talents, the integration of basic and professional courses is still the trend and mainstream in teaching. Combined with the setting up of basic courses and professional courses of the famous Bauhaus Institute in Germany, the teaching work of domestic masters of artistic design must also focus on the professional knowledge of the basic course and integrate it into professional theories and practices, which can continue to strengthen the students' awareness of the discipline and the spirit of innovation and lay a good foundation for improving the level of artistic design.

\section{Combination of Theoretical and Practical Courses}

The combination of theoretical courses and practical courses is the essence of art design education, and it is also an embryonic form of the "dual-track teaching" advocated by master teaching in China. From an objective point of view, a styling teacher is invited for each course, and the styling teacher will share the lessons with other teachers. In the course introduction and analysis, students will continue to accept the influence of various disciplines and content, and thus form a good learn inertia and improve the overall level of art and technology.

\section{Combination of Professional Foundation and Project Foundation Course}

The study of professional foundation and project foundation course is one of the links that must be experienced by each postgraduate. According to the characteristics of the art design major, the study of its professional foundation and project foundation course should highlight the order of the basic and post-professional courses. It is also necessary to pay attention to the integration point between the virtual enterprise and focus on the research and application of education. For example, in education, students can be guided to learn some current more advanced fashion design cases focusing on learning their advancement and application rather than just designing a specific work.

\section{The Combination of Holiday Class and Social Class}

The emergence and development of holiday classes provides a good platform for improving the level of social practice. For postgraduate students, they are relatively mature in age and are more likely to contact and learn social practice knowledge. In teaching, teachers should also encourage students to go out and participate in some summer practice activities. By enhancing the combination and stability of teaching in the social classroom, teachers will create a new cultivation environment and growth conditions for students' comprehensive practical ability. This is also one of the important strategic concepts for cultivating practical and innovative talents in China at this stage.

\section{Part Three Practicing Innovation Talents Course Training Strategy}

Scientific innovative talent training strategies can not only improve the effectiveness of practical teaching, but also provide clear ideas and training directions for cultivating innovative and applied talents. For postgraduates of art design major, choosing a more reasonable and scientific talent training strategy needs pay attention to the following specific tasks.

\section{The Course Structure is Modular}

The modular of curriculum structure is one of the issues that must be paid attention to in the current innovation-practice talent training strategy. By forming a variety of related courses into specific modular courses, the relationship between the various courses and the integrated application relationship are strengthened, which in turn makes the entire course system form a 
rational and scientific structure and create conditions for sub-modules of the course professional relationship sub-module. It is worth noting that under the influence of the modular teaching of the course structure, students can quickly become familiar with the relationship between various modules and knowledge so as to raise the awareness of the entire profession.

\section{The Teaching Methods are Diversified}

Diversification of teaching methods refers to the integration of classroom teaching and extracurricular teaching into the scope of management. Specifically, classroom teaching can be divided into lecture styles and commentary styles. The corresponding adaptability will also show in different course teaching. If it can be expressed in combination with the corresponding teaching mode, the actual teaching effect will be different. In addition, in the teaching process, students can be independently completed by arranging targeted curriculum systems. During the process, they should not give too much guidance, and they can also effectively exercise students' self-learning awareness and learning ability. For example, in classroom teaching activities, students are required to participate in special research and collection of learning materials and learning independent creative and production. In addition, the professional practice process also requires students to practice in conjunction with their actual needs so as to achieve a good teaching practice.

\section{The Visualization of Case Teaching}

Case teaching method is a teaching method commonly used in the art design major. Its visual effects are often more prominent than other teaching methods. This aspect is an advantage of the excellent design case explanation, and on the other hand, it is one of the characteristics of the legend demonstration. With encouraging teachers to present their own design paradigms, they can also do a good job of analyzing and making case studies to ensure the stability and effectiveness of the visual material system of the teaching model so as to display teaching resources to students in an intuitive manner and improve teaching effect.

\section{Professional Practice is Regular}

With the continuous development of the times, the current needs and requirements of employers for professional talents have been continuously improved. In particular, the requirements for practical ability are particularly demanding. Postgraduates belong to the top talents in the art design profession, and they must have good professional practice skills. This is also one of the basic and inevitable requirements for carrying out regular teaching of professional practice in colleges and universities. By allowing students to personally participate in and experience the project process, familiarize themselves with practical skills and links and then comprehensively improve the practical ability and professional adaptability of professional students, they can lay the foundation for the successful completion of employment in the future.

\section{Conclusion}

In summary, practicing innovative talents is one of the most popular types of talents currently employed by social employers. With the successive expansion of major colleges and universities, the current application-oriented talents cultivation strategy for art design postgraduates is also in major comprehensive universities, and art institutions have been successively launched. Taking into account the special nature of the profession, the author also focuses on the analysis of the integrated professional and planning curriculum system and the deployment of the talent cultivation strategy. The author proposes the modular of the curriculum structure, the visualization of the case teaching, the regularization of professional practice and the standardization of teaching management to create new conditions for the smooth implementation of the talent training strategy in China.

\section{Reference}

[1] Yinghui Li. Discussion on the teaching model of postgraduates in design major -- Taking the course of animation major of the College of art and design of Shenzhen University as an example[J]. Art Education,2017(Z4):251-252. 
[2] Huaming Huang, Yunting Gao. Thinking about the curriculum structure of master degree graduate students in art design[J].Art Education Research,2014(17):48-50.

[3] Zimeng Meng. Study on self-cultivation of art design graduates[J].Journal of Educational Science of Hunan Normal University,2013,12(06):101-102.

[4] Yang Gao.Teaching exploration of the course of cultural history for the graduate students of art and design[J].Art Education,2012(05):38.

[5] Jinxian Zhang.The construction of the innovative education model for the postgraduates of the art design major[J].Heilongjiang Higher Education Research,2011(06):72-74. 